\author{
S.V.Zhartovskyi ${ }^{1}$, \\ orcid.org/0000-0001-7512-0988, \\ T.V. Maglyovana ${ }^{2}$, \\ orcid.org/0000-0002-6780-9045
}

1 - Ukrainian Research Institute of Civil Protection of State Emergency Service of Ukraine, Kyiv, Ukraine

2 - Cherkasy Institute of Fire Safety Named after Chornobyl Heroes of National University of Civil Defence of Ukraine, Cherkasy, Ukraine, e-mail: maglovana_t@ukr.net

\title{
RATIONALE OF USE OF GUANIDINE SURFACTANTS FOR FIRE EXTINGUISHING IN NATURAL ECOSYSTEMS
}

Purpose. The rationale for the use of environmentally acceptable polymer surfactants of the guanidine series to increase the fire extinguishing efficiency of water when extinguishing fires in natural ecosystems.

Methodology. Studies on the criteria for the effectiveness of aqueous solutions of polymer surface active agents of the guanidine series in quenching model fire 1A. Field tests of aqueous solutions of guanidine polymers in a stream with a high jet velocity were carried out using a water fire extinguisher VVSH-9 (produced by Makiivka Plant "Fakel” JSC).

Findings. It has been established that the addition of small concentrations of solutions of polymer surfactants of the guanidine series to water leads to an increase in the range of the jet supply by 20-30\% using a water extinguisher VVSH-9; accelerating the supply of charge of the VVSH-9 fire extinguisher by 20-22\%; reducing the time of extinguishing the quenching model fire 1A by $15-20 \%$; increasing fire extinguishing efficiency of water by $1.98-2.23$ times. It has been experimentally established that the use of a $6 \%$ SFPM foaming agent solution makes it possible to extinguish quenching model fire $2 \mathrm{~A}$ with a total area of $9.36 \mathrm{~m}^{2}$, and the use of polyhexamethylene guanidine urea phosphate solution makes it possible to extinguish a quenching model fire $3 \mathrm{~A}$ with a total area of $13.89 \mathrm{~m}^{2}$. The fire extinguishing ability of the solutions of polyhexamethylene guanidine urea and SFPM foaming agents has been calculated, which is 0.55 and $0.93 \mathrm{~kg} / \mathrm{m}^{3}$, accordingly. It is shown that the investigated solutions of guanidine polymers have a higher fire extinguishing efficiency compared to the SFPM foaming agent under these technological conditions, which is possibly associated with a decrease in energy dissipation and loss of friction of the turbulent flow.

Originality. The obtained results indicate a significant improvement in the fire extinguishing properties of the studied aqueous solutions of guanidine polymers compared to water. This is directly related to the improvement in the fluidity of aqueous solutions of polyhexamethylene guanidine salts in the studied range of concentrations, which proves that polymer features hydrodynamic activity and the ability to reduce the hydrodynamic resistance of water, as a result of which an increase capacity of pipelines may take place, in particular in primary fire fighting equipment.

Practical value. The obtained results create the prerequisites for the successful use in practice of polymer surfactants of the guanidine series as highly effective additives to water to increase the efficiency of fire fighting in natural ecosystems.

Keywords: surfactants, polyguanidines, polyhexamethylene guanidine carbamide phosphate, hydrodynamic activity, phosphoruscontaining antipenes

Introduction. Nowadays about 7 million fire incidents, causing huge economic and ecological damage, are registered in the world annually. More than a half of all fire incidents occur in premises and in vehicles, others - in the open air, among those forest fires take an essential place [1].

The large forest fires that took place during the last decade showed increase in vulnerability of forests to fires [2, 3].

To counteract the growing risk of conflagration in the forest ecosystems, effective methods are being searched for all over the world, which is especially urgent in the conditions of the climate changes and extermes [1].

Open fire is one of the most dangerous factors for people, the environment, firefighters who are at risk of the harmful effects of high temperature, thermal radiation, along with the negative effects of products of complete and incomplete combustion [4].

Unfortunately, not always fire extinguishing corresponds to the expected level of efficiency and effectiveness, which does not allow eliminating a fire as soon as possible at the initial stage and thus minimizing the captured area and ecological damage.

Water is the most widely used means for fire extinguishing due to its thermal properties which make it perfectly suit as a means for this aim in most types of fire incidents namely in forest ecosystems.

But water also has some negative properties for fire extinguishing, for example, a high value of surface tension and low viscosity, as a result of which it quickly drains from vertical surfaces and a sufficient amount of it may simply not be involved in extinguishing a fire. Improving the fire extinguishing properties of water and, accordingly, reducing the thermal ef-

(C) Zhartovskyi S. V., Maglyovana T.V., 2020 fect on rescuers can be achieved by using aqueous solutions of surface-active substances (surfactants) and polymers in fire extinguishing systems.

These substances are introduced into the fire hoses and pipelines, which allows increasing the flow rate of the extinguishing agent, the delivery range of the extinguishing agent, as well as reducing the time of the extinguishing operation and, accordingly, improving working conditions during emergency rescue operations by increasing the distance from the rescuer to the fire source [5].

But the use of certain surfactants and polymers as fire extinguishing agents can have negative environmental consequences. Recently, special attention has been paid to the environmental component of the extinguishing agents used [6]. The developed countries of the world create restrictions on the concentration of harmful substances in fire extinguishing agents, but the requirements of the standards that are observed in the USA, Europe and China are not always the same.

Literature review. All recent surfactants in connection with their biochemical decomposition are divided into 3 groups [7]:

1) surfactants, the level of biochemical decomposition of which constitutes $85 \%$ and more - "biologically soft";

2) surfactants, the level of biochemical decomposition of which constitutes $70-85 \%$;

3) surfactants, the level of biochemical decomposition of which is less than $70 \%$ - "biologically tough".

"Biologically tough" surfactants are considered to include hydroxyethylated alkyl phenols (OP-7, OP-10), and among anionic substances there are considered to be alkylaryl sulfonates with branched alkyl chains (such as sulfonol NP-I, soluble alkylaryl sulfonate, wetting agent NB). Also among "biologically tough" foaming agents there are expensive foaming agents with fluorinated surfactants [8]. However, applying 
them under controlled conditions is considered appropriate due to the high fire extinguishing performance film forming foaming agents with fluorinated surface active substances when extinguishing fires in large tanks including water-soluble (polar) organic liquids [9].

The research concerning protection of the environment has proved ecological hazard of surfactants based on perfluorooctane carboxylate acid (PFOA) and perfluorooctane sulfonate acid (PFOS). These surfactants are extremely stable in natural ecosystems, not amenable to hydrolysis, are not used by microorganisms, are present in water and soil, are toxic, migrate along food chains and are bioaccumulated [10]. It has been established that both products (PFOA and PFOS) form equal environmental threat. That is why since 2000 they have been considered persistent organic pollutants and their manufacturing and usage in the USA, Canada and EU countries have been limited [11].

Experimentally, it has been established that fluorosynthetic foaming agents are 150 times more toxic than "biologically tough" foaming agent PO-6K and 2500 times more stable to biochemical decomposition in the environment [11]. The decision of the U.S. Environmental Protection Agency to announce the voluntary discontinuation of the program of using those substances has proved ecological hazard of those foaming agents

It should be mentioned that the authors of this work [12] state that traditional anionic foaming agents are more toxic in comparison with fluorinated foaming agents. It means that investigated foaming agents do not correspond to the expected demands as on their effectiveness and environmental safety.

As a large group of surfactants hardly decompose in course of time and very slow compose under the influence of ultraviolet, absorbing on the surface of dispersed minerals, bottom sediments and other natural colloidal systems, thus breaking ecological balance, European countries have signed the agreement which states that surface active agents, used for industrial and domestic purposes must contain not less than $80 \%$ biodegradable surface active agents [12].

That is why for the aim of environmental protection and rational usage of natural resources surfactants of the third group, "biologically tough", are gradually replaced by surface active substances of the first and second groups [13].

It is worth mentioning that the use of surfactants in fire extinguishing can cause negative consequences for the health of fire brigade personnel too. While dissolved solutions, especially in case they are placed on unprotected skin only once, do not have any side effects, the repeated effect of concentrated surface active agents' solutions can cause dermatitis. Active (diluted) solutions of surfactants at frequent repeated effect on eyes can cause slight corneal clouding which disappears after a while. Concentrated solutions of surfactants while contacting eyes cause inflammation which can lead to corneal clouding that may remain for a month. At repeated effect of surfactant solutions on eye tissues, irreversible changes can occur. While working with surfactant solutions, especially concentrated ones, a person must thoroughly protect their eyes. In case of contact of surfactant with eyes, a person should wash them with a large amount of water or $2 \%$ solution of boric acid, which in most cases reduces the inflammatory process [14].

Having effected the human organism, surfactants are able to accumulate in cell diaphragms, covering their surface with a thin layer and at certain concentration can cause breaking of the most important biochemical processes, stimulate resorption of substances in gastrointestinal tract, increase the blood cholesterol; change liver excretory function; change water and electrolyte balance; disrupt redox processes in the body; form real reasons for strengthening toxic action of a mixture of substances even if these substances get into organism in small quantities [15].

One of the ways of increasing environmental parameters of fire extinguishing agents is the creation of ecologically safe foaming agents [15], which contain surfactants of vegetative and animal origin. They gave start to the use of foam extinguishers at the beginning of the last century. As foaming agents were used extracts of liquorice and soap root, the processed products of biomass hydrolysates. In some European countries protein foaming agents are used nowadays due to their high environmental indicators. There has appeared information as to emerging new foaming agents with high environmental characteristics based on the hop extract [16].

But as to their fire suppressing and economical parameters they essentially yield to synthetic foam agents used nowadays.

That is why the search of ecologically safe and effective foaming agents is an urgent task.

Unsolved aspects of the problem. To our mind, the solution of the problems connected with raising the effectiveness of the use of water for fire extinguishing in natural ecosystems is possible on the account of the use of biodegradable polymeric surfactants from series of polyalkylene guanidines.

Some of the most investigated representatives of polyalkylene guanidines are polyhexamethylene guanidine hydrochloride (PHMG-HC), polyhexamethylene guanidine hydrophosphate (PHMG-HP) and polyhexamethylene guanidine carbamide phosphate (PHMG-CP) which belong to IV low hazard class in case of contact with skin (in accordance with State Standart GOST 12.1.007) [17].

Besides, salts of polyhexamethylene guanidine at the same time demonstrate qualities of surfactants and polymers that allows to use them as effective water fire extinguishing means for fire suppression in natural ecosystems.

Purpose. The goal of this work is rationale of the use of ecologically acceptable polymeric surfactants from series of guanidines and the elaboration of their composition for increasing fire extinguishing ability of water to suppress fires in natural ecosystems.

Methods. Polyhexamethylene guanidines, investigated in the work, have been received by the way of polycondensation of the salt of guanidine with diamine in the presence of organic acid or mixture of organic acids in the presence of inorganic salt at gradual heating to the temperature $120-130{ }^{\circ} \mathrm{C}$ during one hour with the gradual raising of temperature to $150-160{ }^{\circ} \mathrm{C}$, which is being kept for $3.5-4$ hours with the gradual raising of temperature to $170-180{ }^{\circ} \mathrm{C}$, kept for $1-1.5$ hour [17].

The polyhexamethylene guanidines received by this method are characterized by low content of the residual amount of monomer and can be used for getting fire extinguishing means at ultra low content of surfactant in fire extinguishing solutions, which corresponds to high ecological requirements of environmental protection and rational use of natural resources.

Being cationic polyelectrolytes, they are effectively absorbed by components which pollute water. After transferring into the bottom phase the processes of their biodegradation essentially accelerate, which is expressed in reducing by $80 \%$ concentration of guanidine substances even after the first pass through the layer of an "active sludge".

In the experimental studies medium hard tap water, solutions of salts PHMG and foam agent SFPM in concentration range $0-6 \%$ were used. The used salts of PHMG-HC, PHMG-HP and PHMG-CP with a molecular weight of 10000-11000 u

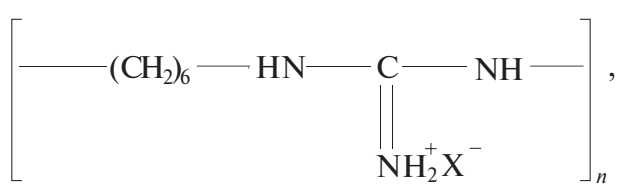

where $\mathrm{X}-\mathrm{HCl}, \mathrm{HPO}_{4}^{2-}, n=30-90$.

Aqueous solutions of salts PHMG were received by dissolving precision hinges in distilled water. The solutions were left for 24 hours at the temperature of $25 \pm 5{ }^{\circ} \mathrm{C}$ till their complete dissolution. 
The research on performance criteria of studied water fire suppression means at extinguishing of quenching model fire was conducted according to the methodology, created in coordination with Ukrainian Civil Protection Research Institute (UkrCPRI) [18].

The essence of this methodology involves the definition of fire suppression effectiveness of water fire extinguishing means on accounts of their mass determination which is needed to supply (under the same conditions) to extinguish quenching model fire "A" class with the use of a water fire extinguisher VVSH-9 (manufactured by JSC "Makiivka Plant "Fakel", Kyiv).

The relative fire extinguishing effectiveness of the investigated solutions and water was determined by using the facility, whose scheme is shown in Fig. 1.

The mass of the substance spent on fire extinguishing was calculated by the formula

$$
\Delta m=m_{1}-m_{2},
$$

where $m_{1}$ is fire extinguisher tank mass before experimental studies $(\mathrm{kg}) ; m_{2}$ is fire extinguisher tank mass after extinguishing $(\mathrm{kg})$.

The relative efficiency $\mathrm{Z}$ was determined by the formula

$$
Z=\Delta m_{w} / \Delta m_{\text {wea }},
$$

where $\Delta m_{w}$ is mass of the water which was used to extinguish quenching model fire "A" class $(\mathrm{kg}) ; \Delta m_{\text {weac }}$ is mass of water extinguishing agent which was used to extinguish quenching model fire "A" class $(\mathrm{kg})$.

The investigation in the range of the jet supply, the accelerating the supply of charge time, the time of extinguish quenching model fire " $\mathrm{A}$ " class was conducted with the use of a water fire extinguisher VVSH-9 (manufactured by "Makiivka Plant "Fakel" JSC, Kyiv) according to [19].

Results. It has been established by the conducted experimental research that polymere addition promotes:

- the extending range of the jet supply by $20-30 \%$ with use of water fire extinguisher VVSH-9;

- acceleration of the supply of the charge of water fire extinguisher VVSH- 9 by $20-22 \%$;

- reduction of time extinguish quenching model fire "A" class by $15-20 \%$;

- increasing fire suppression effectiveness of water extinguish quenching model fire "A" class by almost 1.98-2.23 times (Table 1).

To our mind, substantiation of the received results is contained in the following.

The used PHMG is a linear polymer, referred to the class of strong polybases and polyelectrolytes in the consequence of electrolytic dissociation of which macroions and counterions

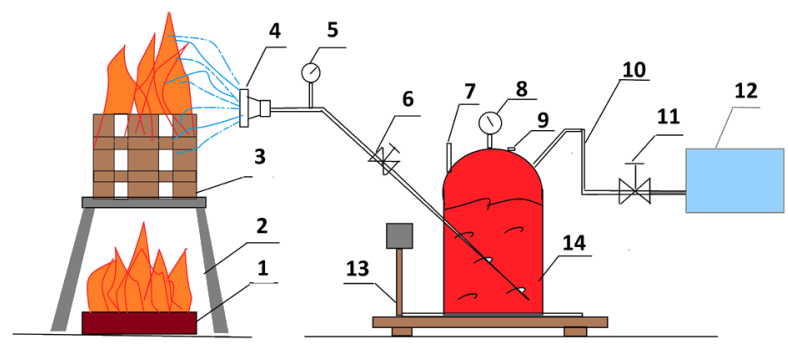

Fig. 1. Scheme of facility for determination of relative fire suppression effectiveness of water fire extinguishers to fires of "A" class:

1 - metal deco for flammable liquid; 2 - metal tripod; 3 quenching model fire "A" class; 4 - water extinguishing agent sprays (2 units); 5, 8-manometers; 6, 11-stopcocks; 7-safety valve; 9 - neck for charging containers with extinguishing agent; 10 - connecting pipelines; 12 - compressor; 13 - scales; 14 - fire extinguisher tank (VVSH-9)
Table 1

Mid-range results of the determination of relative fire suppression effectiveness of water extinguish agents (fire class - 1A)

\begin{tabular}{|l|c|c|}
\hline Water fire extinguish agent & $\begin{array}{c}\text { Average weight } \\
\Delta m, \text { of the agent } \\
\text { consumed for fire } \\
\text { extinguish, kg }\end{array}$ & $\begin{array}{c}\text { Relative fire } \\
\text { suppression } \\
\text { effectiveness } Z\end{array}$ \\
\hline Water & $9 \pm$ & 1.00 \\
\hline $\begin{array}{l}\text { Water + } 2 \% \text { foaming agent of } \\
\text { Pirena type }\end{array}$ & $5.42 \pm$ & 1.66 \\
\hline PHMG-HP & $4.45 \pm$ & 1.98 \\
\hline PHMG-CP & $4.03 \pm$ & 2.23 \\
\hline
\end{tabular}

are formed. PHMG ionogenic guanidine groups give the polymere the properties of a cationic polyelectrolyte, which has a polyelectrolyte effect in dilute solutions - the effect of swelling of macroclubs when exposed to positive charges on the macromolecule chain. It is possible that under these conditions polymere molecules greatly swell in water having filamentous structure and, as a result, they pull along the flow under the effect of the liquid flow, intensifying fluidity in wall areas, which promotes the raise of range of the jet supply and acceleration of water fire extinguisher VVSH-9 (Table 1), and as a consequence of supply of large amount of water for a certain time, it is possible to reduce the time of fire extinguishing a quenching model fire "1A" class by 15-20\% (Table 1).

Adsorption on walls of the pipeline of PHMG salts in presence of a secondary amino group in the guanidine group with the formation of a sufficiently stable adsorption layer can also have a significant effect on the reduction of hydrodynamic resistance by guanidine polymers. Thus, macromolecules of polymer increase the wall (laminar) layer on the inner surface of pipes. And, since each PHMG macromolecule is covered by water tetramers (due to association), their interaction with the formation of hydrogen bonds can lead to water structuring and also to an increase in fluidity at wall regions.

The further field studies involving the use of water fire extinguisher VVSH-9 were directed to revealing fire extinguishing ability of solutions PHMG-CP in comparison with regular charge of the given fire extinguisher (6\% solution of foaming agent SFPM).

Using $6 \%$ solution of foaming agent SFPM, it was possible to suppress a quenching model fire " $2 \mathrm{~A}$ " class, with the total area of $9.36 \mathrm{~m}^{2}$, and using the solution PHMG-CP made it possible to suppress a quenching model fire " $2 \mathrm{~A}$ " class, with the total area of $13.89 \mathrm{~m}^{2}$. Taking into consideration the received data, indices of fire extinguishing ability of the solutions under study were calculated, which are demonstrated in Table 2 .

The investigated solutions PHMG have higher fire extinguishing effectiveness in comparison with foaming agent SFPM at the given technological regimes, which can be related to reduced energy dissipation and friction loss in turbulent flow [20]. As the presence of secondary amino group in the polymere allows the PHMG salts to adsorb on the surface, that can lead to reducing friction.

Table 2

Fire extinguishing ability of solutions PHMG-CP and foaming agent SFPM

\begin{tabular}{|l|c|}
\hline \multicolumn{1}{|c|}{ Fire extinguish agent } & Fire extinguishing ability, $\mathrm{kg} / \mathrm{m}^{2}$ \\
\hline PHMG-CP & 0.55 \\
\hline SFPM & 0.93 \\
\hline
\end{tabular}




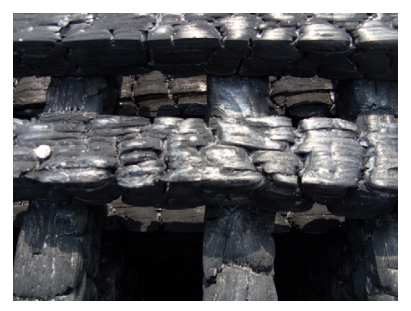

$a$

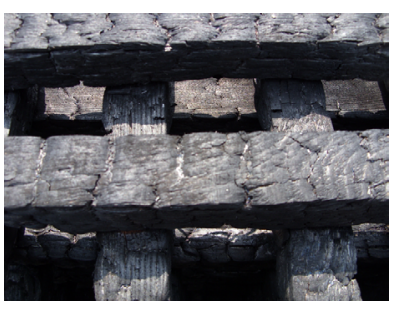

Fig. 2. Photo of quenching model fires "1A" class after the suppression by:

$a-$ water; $b-P H M G-C P$

In Fig. 2. there is a photo of quenching model fires " $1 \mathrm{~A}$ " class after the suppression by water (a) and PHMG-CP (b).

Visual analysis of the samples after suppression allows drawing conclusions as to prospects for the use of PHMG-CP as fire extinguishing means for cellulose-containing materials. To our mind, this can be related to two factors: the presence of phosphorus ions of guanidine compounds $\left(\mathrm{H}_{2} \mathrm{PO}_{4}^{-}, \mathrm{HPO}_{4}^{-}\right.$, $\mathrm{PO}_{3}^{-}, \mathrm{PO}^{+}, \mathrm{P}_{2} \mathrm{O}, \mathrm{P}_{2} \mathrm{O}_{2}^{+}, \mathrm{P}_{2} \mathrm{O}_{3}^{+}$) which increase efficiency of both homogeneous and heterogeneous inhibition of reactions combustion; as a result, a reduction in the time of extinguishing the class fire $1 \mathrm{~A}$ is achieved. $\mathrm{P}-\mathrm{N}$ synergism promotes the formation of cross-linked networks with polymer chains during a fire, thereby encouraging the retention of $\mathrm{P}$ in the condensed phase and yielding higher and more thermally stable char formation [21].

Or it can also be associated with the fact that the received finely sprayed jets increase vaporization in the area of combustion thus raising cooling and phlegmatizing effects.

The received results allow speaking about considerable improvement of fire extinguishing qualities of the investigated aqueous solutions of guanidine polymers in comparison with water use which is directly associated with the improvement of fluidity of aqueous solutions PHMG in the researched range of concentration, that is about presence of the hydrodynamic activity in polymere PHMG, ability to reduce hydrodynamic resistance of water on account of which it is possible to increase capacity, in particular, primary fire extinguishing means [17].

Due to their chemical structure the researched polymere surface active agents of guanidine series are able to realize several parameters of the cessation of combustion: inhibition, phlegmatization, cooling and do not contain components, which, with regard of their effect on the organism, are considered dangerous and extremely dangerous. The use of these surfactants makes them promising for developing a solution for fire extinguishing on their basis. Phosphorus is pivotal to the development of novel efficient flame retardants, mainly because of its chemical versatility: it can act in both the condensed and gas phases, as an additive component or as a reactive one, in various oxidization states, and in synergy with numerous adjuvant elements [21].

PHMG salts have a wide range of biocidal effect: bactericidal, virucidal, sporocidal, fungicidal and algicidal) [17]. A wide range of biocidal effect of polyalkylene guanidines is conditioned by the presence of guanidine groups in repeating units of macromolecules polymers of polyalkylene, which are an active base for some natural and synthetic medicines and antibiotics (sulgin, ismelin, pharyngosept, streptomycin) making them promising in the sphere of disinfection in emergency.

A great value of polyguanidines is the absence of volatility, good dissolving capacity, absence of smell, colour, unaggressiveness to various materials, biodegradability and safety for environment. Besides PHMG-HC is inhibitor of biocorrosion of metal equipment; it prevents the forming of biofilm, remove components of biocenosis of fouling and iron salts, stored in old pipelines [17].
The polymere researched in the work has the qualities of "biologically soft" surfactant and corresponds to high ecological demands of environment and rational use of natural resources. It can be used for developing ecologically acceptable water fire extinguishing means and during fire-fighting operations.

\section{Conclusions.}

1. Approaches to the estimation of negative impact of foaming agents used nowadays on the environment and people are considered. The use of ecologically acceptable polymere surfactants of guanidine series is grounded for fire extinguishing in natural ecosystems.

2. It has been established that small amounts of polyhexamethylene guanidine salts added into water, on the account of reduction of hydraulic losses, allow raising the amount of fire suppressing substance used at flash point by $1.5-2.0$ times; improving fire suppressing qualities of water by $1.98-2.23$ times (depending on the concentration of polymere and its salt composition), and also increasing the range of fire extinguishing agent in primary fire extinguishing means of fire suppression by $20-30 \%$ with the use of the fire extinguisher VVSH-9.

3 . The use of "biologically soft" surface active agents, which simultaneously have the properties of polymers, in the composition of modern fire suppression means allows improving indices of fire suppressing and ecological safety.

\section{References.}

1. Dube, P. (2013). Challenges of wildland fire management in Botswana: Towards a community inclusive fire management approach Weather and Climate Extremes, 1, 26-41.

2. Zibtsev, S. V., Soshenskyi, O. M., Gumeniuk, V.V., \& Koren, V. A. (2019). Long term dynamic of forest fires in Ukraine. Ukrainian Journal of Forest and Wood Science, 10(3), 27-40. 3. Forest fires in Europe, Middle East and North Africa 2018. Publications Office of the European Union, Luxembourg. ISBN: 978-92-76-11234-1, https://doi.org/10.2760/1128.

4. Abrard, S., Bertrand, M., Timothée, D.V., \& Schaupp, T. (2019). French firefighters exposure to Benzo[a]pyrene after simulated structure fires International Journal of Hygiene and Environmental Health, 222, 84-88.

5. Yasnyuk, T., Vyazkova, E., Anisimova, E., Tsyrendashiev, N., Panasenko, N., \& Tsybulia, I. (2018). The use of water-soluble polymers to reduce hydraulic friction resistance. Bulletin of Eurasian Science, 10(3).

6. Hayder A.Abdulbari, Ainoon Shabirin, \& Abdurrahman, H. N. (2014). Bio-polymers for improving liquid flow in pipelines - A review and future work opportunities. Journal of Industrial and Engineering Chemistry, 20(4), 1157-1170. https://doi.org/10.1016/j.jiec.2013.07.050.

7. Pletnev, M. (2001). Chemistry of surfactants. Studies in Interface Science, 132001, 1-97.

8. Luab, Y., Wang, T., Pang, M., \& Tian, Z. (2018). Preparation and High Temperature Resistance of a Novel Aqueous Foam for Fire Extinguishing. Procedia Engineering, 211, 514520.

9. Taysumov, Kh.A. (2018). The composition of heat-resistant foam for the prevention and extinguishing of fires. International Journal of Applied and Basic Research, (2), 49-52.

10. Amirova, Z. K., \& Speranskaya, O.A. (2016). New persistent organic supertoxicants and their impact on human health: monograph. Moscow.

11. European Chemical Agency [UNEP-POPS-PFOS] (n.d.). Retrieved from http://echa.europa.eu/web/guest/information-on-chemicals/cl-invento-rydatabase.

12. Dadashov, I., Kireyev, A., \& Zhernoklev, K. (2017). Ways of enhancing ecological characteristics of agents for extinguishing flammable liquids. Technogenic and Ecological Safety, (1), 39-43.

13. Hill, C., Czajka, A., Hazell, G., Grillo, I., \& Eastoe, J. (2018). Surface and bulk properties of surfactants used in firefighting Journal of Colloid and Interface Science, 53015, 686-694. 
14. Shcherban, N. (2012). Biochemical mechanisms of disturbances in the organism of warm-blooded under the influence of chemical compounds. East European Journal of Advanced Technologies, 5/6(59), 29-33.

15. Bezrodnyy, I. F. (2013). Ecology of fire extinguishing is for now only words. Pozharovzryvobezopasnost, 22(6), 85-90.

16. Taysumov, Kh.A. (2012). Russian Federation Pat. No. 2452544. Russian Federation.

17. Maglyovana, T.V., Nyzhnyk, Y.U., \& Zhartovsiy, S.V. (2017). Environmental aspects of the use of guanidine polymers in emergency situations: monograph ( $2^{\text {nd }}$ ed.) Cherkasy: Publisher FOP Gordienko E.I.

18. Zhartovskiy, S. (2018). Use of salts of polyhexamethylene guanidine in the composition of fire-extinguishing substances for protivopojezhnuyu zhistu ob'ektiv in iz cellulose materials], Scientific Bulletin of UNFU, 28(6), 93-98.

19. DSTU 3675-98. Fire-fighting equipment. Portable fire extinguishers. General technical requirements and test methods (n.d.). Retrieved from https://dnaop.com/html/41026/doc-\%D0\%9 4\%D0\%A1\%D0\%A2\%D0\%A3 3675-98.

20. Xi, L. (2019). Turbulent drag reduction by polymer additives: Fundamentals and recent advances. Physics of Fluids, 31. https://doi.org/10.1063/1.5129619.

21. Velencoso, M., Battig, A., Markwart, C., Schartel, B., \& Wurm, R. (2018). Molecular Firefighting - How Modern Phosphorus Chemistry Can Help Solve the Challenge of Flame Retardancy. Angewandte Chemie International Edition, 57(33),10450-10467. https://doi.or-g/10.1002/anie.201711735.

\section{Обгрунтування використання поверхнево-активних речовин гуанідинового ряду для гасіння пожеж у природних екосистемах}

\section{С. В. Жартовськийㄴ, Т. В. Магльована ${ }^{2}$}

1 - Український науково-дослідний інститут цивільного захисту Державної служби України з надзвичайних ситуацій, м. Київ, Україна

2 - Черкаський інститут пожежної безпеки імені Героїв Чорнобиля Національного університету цивільного захисту України, м. Черкаси, Україна, e-mail: maglovana_t@ukr.net

Мета. Обгрунтування застосування екологічно прийнятних полімерних поверхнево-активних речовин гуанідинового ряду для підвищення вогнегасної ефективності води при гасіння пожеж у природних екосистемах.

Методика. Дослідження критеріїв ефективності водних розчинів полімерних поверхнево-активних речовин гуанідинового ряду при гасінні модельних вогнищ класу А. Натурні випробування водних розчинів гуанідинових полімерів у потоці з високою швидкістю струменя проводили з використанням водного вогнегасника ВВШ9 (виробництва ПрАТ «Макіївський завод «Факел»).

Результати. Встановлено, що додавання до води невеликих концентрацій розчинів полімерних поверхневоактивних речовин гуанідинового ряду призводить до збільшення дальності подачі струменя на 20-30\% з використанням водного вогнегасника ВВШ-9; прискорення викиду заряду вогнегасника ВВШ-9 на 20-22 \%; скорочення часу гасіння модельного вогнища пожежі $1 \mathrm{~A}$ на 15-20\%; підвищення вогнегасної ефективності води в 1,98-2,23 рази. Експериментально встановлено, що використання $6 \%$-вого розчину піноутворювача SFPM дає можливість загасити модельний осередок пожежі класу $2 \mathrm{~A}$, загальною площею $9,36 \mathrm{~m}^{2}$, а застосування розчину полігексаметиленгуанідин фосфат карбаміду дає можливість загасити модельний осередок пожежі класу $3 \mathrm{~A}$, за-

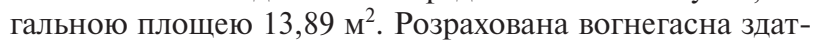
ність розчинів полігексаметиленгуанідин фосфат карба- міду й піноутворювача SFPM, що становить, відповідно, 0,55 і 0,93 кг $/ \mathrm{M}^{3}$. Показано, що досліджувані розчини гуанідинових полімерів мають більш високу відносну вогнегасну здатність у порівнянні з піноутворювачем SFPM за даних технологічних режимах, що можливо пов'язано зі зниженням розсіювання енергії та зменшення тертя турбулентного потоку.

Наукова новизна. Отримані результати дозволяють говорити про значне поліпшення вогнегасних властивостей досліджуваних водних розчинів гуанідинових полімерів у порівнянні з водою. Це пов'язано з поліпшенням плинності водних розчинів солей полігексаметиленгуанідину в досліджуваному діапазоні концентрацій, що свідчить про наявність у полімеру гідродинамічної активності, здатності знижувати гідродинамічний опір тертя, унаслідок чого можливе збільшення пропускної здатності трубопроводів, зокрема, в первинних засобах пожежогасіння.

Практична значимість. Отримані результати створюють передумови для успішного використання на практиці полімерних поверхнево-активних речовин гуанідинового ряду в якості високоефективних добавок до води для підвищення ефективності гасіння пожеж у природних екосистемах для підвищення показників пожежної та екологічної безпеки.

Ключові слова: поверхнево-активні речовини, полігуа нідини, полігексаметиленгуанідин фосфат карбамід, гідродинамічна активність, фосфоровмісні антипірени

\section{Обоснование применения поверхностно-активных веществ гуанидинового ряда для тушения пожаров в природных экосистемах}

\section{С. В. Жартовский ${ }^{1}$, Т. В. Маглеваная ${ }^{2}$}

1 - Украинский научно-исследовательский институт гражданской защиты Государственной службы Украины по чрезвычайным ситуациям, г. Киев, Украина

2 - Черкасский институт пожарной безопасности имени Героев Чернобыля Национального университета гражданской защиты Украины, г. Черкассы, Украина, e-mail: maglovana_t@ukr.net

Цель. Обоснование применения экологически приемлемых полимерных поверхностно-активных веществ гуанидинового ряда для повышения огнетушащей эффективности воды при тушении пожаров в природных экосистемах.

Методика. Исследования критериев эффективности водных растворов полимерных поверхностно-активных веществ гуанидинового ряда при тушении модельных очагов класса А. Натурные испытания водных растворов гуанидиновых полимеров в потоке с высокой скоростью струи проводили с использованием водного огнетушителя ВВШ-9 (производства ЧАО «Макеевский завод «Факел»).

Результаты. Установлено, что добавление к воде небольших концентраций растворов полимерных поверхностно-активных веществ гуанидинового ряда приводит к увеличению дальности подачи струи на 20-30\% с использованием водного огнетушителя ВВШ-9; ускорению выброса заряда огнетушителя ВВШ-9 на 20-22\%; сокрашению времени тушения модельного очага пожара 1А на 15-20\%; повышению огнетушащей эффективности воды в 1,98-2,23 раза. Экспериментально установлено, что использование $6 \%$-ного раствора пенообразователя SFPM дает возможность потушить модельный очаг пожара класса 2А, общей площадью 9,36 м², а применение раствора полигексаметиленгуанидин фосфат карба- 
мида дает возможность потушить модельный очаг пожара класса 3А, общей площадью 13,89 м². Рассчитана огнетушащая способность растворов полигексаметиленгуанидин фосфат карбамида и пенообразователя SFPM, которая составляет, соответственно, 0,55 и 0,93 кг $/ \mathrm{M}^{3}$. Показано, что исследуемые растворы гуанидиновых полимеров имеют более высокую огнетушащую эффективность по сравнению с пенообразователем SFPM при данных технологических режимах, что, возможно, связано со снижением рассеяния энергии и потере трения турбулентного потока.

Научная новизна. Полученные результаты позволяют говорить о значительном улучшении огнетушащих свойств исследуемых водных растворов гуанидиновых полимеров по сравнению с водой. Это непосредственно связано с улучшением текучести водных растворов солей полигексаметиленгуанидина в исследуемом диапазоне концентраций, что свидетельствует о наличии у полимера гидродинамической активности, способности снижать гидродинамическое сопротивление воды, вследствие чего возможно увеличение пропускной способности, в частности, в первичных средствах пожаротушения.

Практическая значимость. Полученные результаты создают предпосылки для успешного использования на практике полимерных поверхностно-активных веществ гуанидинового ряда в качестве высокоэффективных добавок к воде для повышения эффективности тушения пожаров в природных экосистемах.

Ключевые слова: поверхностно-активные вещества, полигуанидины, полигексаметиленгуанидин фосфат карбамид, гидродинамическая активность, фосфорсодержащие антиперены

Recommended for publication by A.S. Bielikov, Doctor of Technical Sciences. The manuscript was submitted 02.12.19. 